\title{
Studi Teknis Genset Termodifikasi Menggunakan Gas Alam dengan Variasi Tekanan Masukan
}

\section{(Technical Study of Modified Genset Using Natural Gas with Different Inlet Pressure)}

\author{
Faiz Husnayain ${ }^{1}$, Agung Budiyanto ${ }^{2}$, Fauzan Hanif Jufri ${ }^{3}$, I Made Ardita Y..$^{*}$
}

\begin{abstract}
Every year Indonesia experiences an increase in the number of electricity customers. However, there are still many areas that do not yet have electricity supply or have frequent disturbances. Therefore, we need a generator set as the main electricity supply or as a backup for these areas. Natural gas can be used as generator fuel because of its abundant availability and is more environmentally friendly. However, the availability of gasfueled generators in Indonesia is still very rare, so that additional equipment such as regulators, converter kits, and air mixing equipment for gas can be used on gasoline generators. Due to this background and its potential, testing is carried out to determine the performance of the modified generator set when using natural gas fuels. The method used is to compare engine performance by varying the value of the generator's input pressure, which is 0.5 and 0.03 bar. The results observed were the SFC value, power quality, exhaust gas temperature, and the noise level produced by the generator. The results of this test are that the voltage and frequency generated is still within the specified normal limits, the exhaust gas temperature and the noise level generated when the input pressure is 0.5 bar and 0.03 bar are relatively the same, and the SFC value generated when the input pressure is 0.5 bar is 5.7$25 \%$ smaller than the SFC value at 0.03 bar input pressure.
\end{abstract}

Intisari-Setiap tahunnya jumlah pelanggan listrik di Indonesia mengalami peningkatan. Namun, di sisi lain, masih banyak daerah yang belum mendapatkan suplai listrik atau sering mengalami gangguan. Oleh karena itu, dibutuhkan generator set (genset) sebagai suplai listrik utama atau cadangan untuk daerahdaerah tersebut. Gas alam dapat digunakan sebagai bahan bakar genset karena ketersediaannya di Indonesia yang melimpah dan ramah lingkungan. Namun, ketersediaan genset berbahan bakar gas di Indonesia masih sangat jarang, sehingga dibutuhkan peralatan tambahan seperti regulator, kit konverter, dan alat pencampur udara dengan gas agar dapat digunakan pada genset bensin. Dengan latar belakang dan potensi tersebut, pengujian dilakukan untuk mengetahui kinerja genset termodifikasi ketika menggunakan bahan bakar gas alam. Metode yang digunakan adalah membandingkan kinerja mesin dengan memvariasikan nilai tekanan masukan genset, yaitu 0,5 bar dan 0,03 bar. Hasil yang diamati adalah nilai SFC, kualitas daya, temperatur gas buang, dan tingkat kebisingan yang dihasilkan genset. Hasil dari pengujian ini adalah tegangan dan frekuensi yang dihasilkan genset masih dalam batas normal yang ditentukan, suhu gas buang dan tingkat kebisingan yang dihasilkan ketika tekanan

1,3,4 Departemen Teknik Elektro dan Electric Power and Energy Studies (EPES), Fakultas Teknik, Universitas Indonesia, Jl. Margonda Raya, Pondok Cina, Beji, Depok, Jawa Barat 16424, INDONESIA (tlp: 021-7270078; *e-mail: i.made61@ui.ac.id)

${ }^{2}$ Departemen Teknik Elektro, Fakultas Teknik Universitas Indonesia, Jl. Margonda Raya, Pondok Cina, Beji, Depok, Jawa Barat 16424, INDONESIA (tlp: 021-7270078) masukan 0,5 bar dan 0,03 bar relatif sama, dan nilai SFC yang dihasilkan ketika tekanan masukan 0,5 bar lebih kecil 5,7-25\% dibandingkan dengan nilai SFC pada tekanan masukan 0,03 bar.

Kata Kunci-Genset Termodifikasi, Gas Alam, Kualitas Daya Listrik, SFC, SAIDI, SAIFI.

\section{Pendahuluan}

Keandalan jaringan listrik di Indonesia mengalami kenaikan dan penurunan yang fluktuatif selama lima tahun (2014-2018) [1]. Penurunan keandalan ini dapat dilihat dari nilai SAIDI dan SAIFI nasional. Pada durasi lima tahun tersebut, rata-rata nilai SAIDI dan SAIFI adalah sebesar 13,172 jam/pelanggan dan 9,282 kali/pelanggan [1]. Tingginya angka SAIDI SAIFI dapat menyebabkan kerugian yang besar, baik bagi pelanggan maupun penyedia listrik itu sendiri, yaitu PLN [2], [3]. Oleh karena itu, untuk menghindari kerugian akibat pemutusan, khususnya di sisi pelanggan, dibutuhkan sumber alternatif lain sebagai penyedia listrik ataupun sebagai cadangan untuk daerah-daerah yang memiliki nilai SAIDI dan SAIFI yang tinggi. Generator set (genset) adalah salah satu alternatif yang dapat digunakan untuk mengatasi masalah yang telah disebutkan. Genset adalah suatu mesin listrik yang bertujuan untuk menghasilkan listrik dengan menggunakan bahan bakar bensin, solar, atau gas.

Ketersediaan gas, khusunya gas alam, di Indonesia sangat tinggi. Pada tahun 2015, Indonesia adalah negara ke-13 dengan cadangan gas alam terbesar di dunia [4]. Selain melimpahnya gas alam di Indonesia, ketersediaan bahan bakar minyak dunia semakin menipis, sehingga perlu dicarikan penggantinya. Gas alam juga merupakan penghasil emisi terendah untuk gas rumah kaca dan emisi lain yang berbahaya bagi kehidupan dibandingkan dengan bahan bakar hidrokarbon lainnya [5]. Berdasarkan kelebihan yang dimiliki oleh gas alam tersebut, penggunaan gas alam sebagai sumber energi bagi genset perlu ditingkatkan, sebagai bahan bakar alternatif pengganti bensin dan solar [6]. Sebagai upaya untuk meningkatkan penggunaan gas alam, Kementerian Energi dan Sumber Daya Mineral (KESDM) melakukan pembangunan jaringan gas (jargas) untuk pelanggan rumah tangga, yang didanai Anggaran Pendapatan Belanja Negara (APBN) dari tahun 2009 hingga tahun 2018. Dana APBN yang digunakan pada pembangunan jargas ini mencapai total sambungan rumah sebanyak 325.773 sambungan [7]. Oleh karena itu, pemanfaatan gas alam sebagai bahan bakar genset dapat menjadi peluang yang baik untuk mengatasi permasalahan yang telah disebutkan di atas.

Namun, realita yang ada menunjukkan ketersediaan genset berbahan bakar gas di Indonesia masih sangat minim 


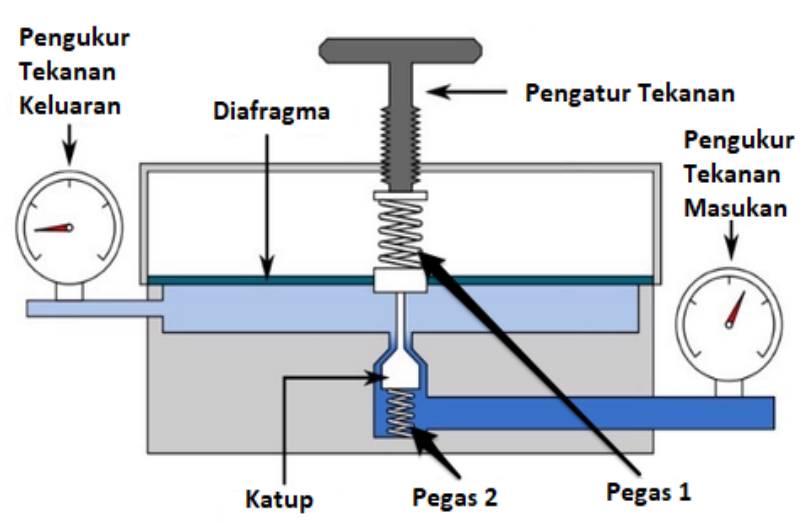

Gbr. 1 Regulator.

jumlahnya. Untuk itu, digunakanlah genset termodifikasi berbahan bakar bensin yang telah ditambahkan alat seperti kit konverter, mixer, dan regulator, agar genset dapat menggunakan bahan bakar gas.

Untuk merealisasikan hal tersebut, dibutuhkan studi teknis terkait penggunaan generator set termodifikasi dengan bahan bakar gas alam. Studi teknis dikaji dengan memvariasikan nilai tekanan masukan. Dua tekanan masukan berbeda digunakan, yaitu 0,03 bar dan 0,5 bar. Tekanan 0,03 bar dipilih karena tekanan ini merupakan besar tekanan gas alam yang biasa digunakan untuk pelanggan rumah tangga, sedangkan tekanan 0,5 bar adalah tekanan minimum genset untuk bekerja tanpa menggunakan tambahan regulator.

\section{KOMPONEN DAN PARAMETER GENSET}

Genset adalah suatu mesin atau perangkat yang terdiri atas pembangkit listrik (generator) dengan mesin penggerak yang disusun menjadi satu kesatuan untuk menghasilkan suatu tenaga listrik dengan besaran tertentu. Mesin pembangkit kerja pada genset biasanya berupa motor yang melakukan pembakaran internal, atau mesin diesel yang bekerja dengan bahan bakar solar dan bensin.

\section{A. Komponen Penunjang Gas Alam sebagai Bahan Bakar Genset Termodifikasi}

Penggunaan gas alam sebagai bahan bakar genset termodifikasi membutuhkan komponen tambahan. Komponen yang dibutuhkan yaitu regulator, mixer, dan kit konverter.

1) Regulator: Regulator merupakan sebuah komponen sistem hidraulis maupun pneumatik yang berfungsi untuk mengatur besar tekanan fluida dari sistem sumber tekanan tinggi ke sistem pengguna bertekanan rendah. Prinsip kerja dari regulator adalah saat mulai beroperasi, pegas diatur untuk memberikan gaya tertentu terhadap katup dengan cara mengatur sekrup/pengatur yang telah disediakan. Katup akan terbuka dan tekanan gas akan mengalir yang menyebabkan tekanan pada outlet meningkat. Lalu, diafragma akan bergerak menyeimbangkan kekuatan pegas karena tekanan gas yang semakin besar, sehingga tekanan pada inlet akan menutup katup. Saat gas sedang digunakan, tekanan pada outlet akan menurun dan pegas dapat melawan diafragma untuk membuat katup cukup terbuka dan kembali dengan tekanan yang

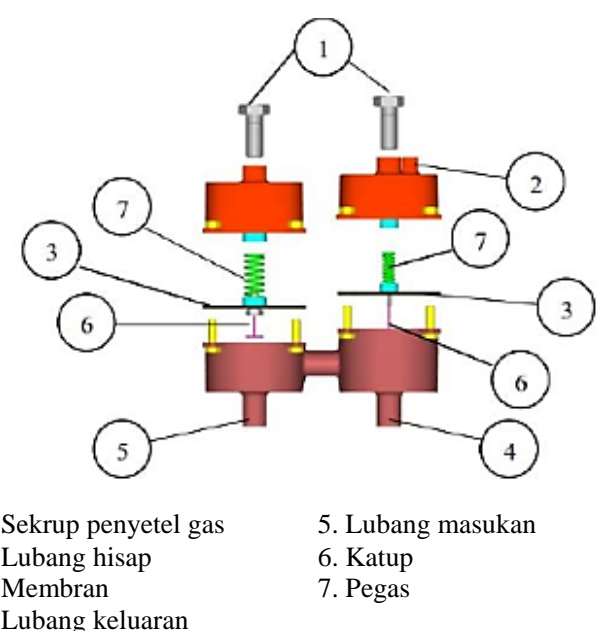

Gbr. 2 Kit konverter.

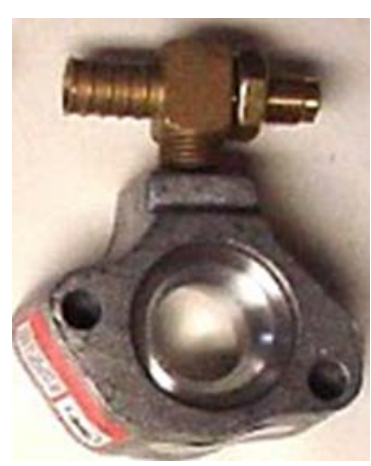

Gbr. 3 Mixer.

diinginkan [8]. Ilustrasi prinsip kerja regulator ini diperlihatkan pada Gbr. 1.

2) Kit Konverter: Kit konverter merupakan seperangkat alat yang digunakan untuk mengonversi mesin berbahan bakar minyak menjadi berbahan bakar gas, tanpa harus mengganti mesin [9]. Setidaknya ada tujuh komponen pada kit konverter yang digunakan pada makalah ini, sehingga memungkinkan gas alam untuk dapat digunakan pada genset yang sudah ada. Hal ini ditunjukkan pada Gbr. 2.

3) Mixer: Mixer adalah sebuah alat yang digunakan untuk mencampur bahan bakar dan udara yang dihubungkan pada regulator dengan selang. Bentuk mixer dipengaruhi oleh spesifikasi mesin yang digunakan, sehingga unik untuk tiap jenis genset yang digunakan. Sebagai gambaran, contoh mixer yang digunakan pada makalah ini ditunjukkan pada Gbr. 3.

\section{B. Parameter Pengukuran}

1) Specific Fuel Consumption (SFC): SFC adalah rasio perbandingan total konsumsi bahan bakar terhadap daya listrik yang dibangkitkan dalam sebuah industri pembangkitan listrik.

$$
S F C=\frac{F C}{E}
$$

dengan

$$
\begin{aligned}
& F C=\text { fuel consumption }\left[\mathrm{m}^{3}\right] \\
& E=\text { energi listrik [kWh]. }
\end{aligned}
$$


2) Kestabilan Tegangan: Parameter kestabilan tegangan merupakan kemampuan dari suatu sistem jaringan listrik untuk mempertahankan nilai tegangan saat beroperasi normal atau setelah terjadi gangguan [10]. Ketidakstabilan tegangan dapat terjadi karena meningkatnya beban yang diterima oleh genset. Tegangan yang dihasilkan terbentuk karena adanya gaya gerak listrik pada kumparan yang terdiri atas beberapa fluks medan magnetik, sesuai dengan hukum Faraday [11].

$$
G G L=-N \frac{d \emptyset}{d t}
$$

dengan:

$$
\begin{aligned}
G G L & =\text { gaya gerak listrik [volt] } \\
N & =\text { jumlah kumparan } \\
\varnothing & =\text { perubahan fluks magnetic [weber] } \\
t & =\text { waktu [s]. }
\end{aligned}
$$

Ketentuan variasi tegangan di Indonesia/grid code yang mengacu pada SPLN 1:1995 adalah $+5 \%$ dan $-10 \%$ dari tegangan nominal yang telah ditentukan, yaitu $230 \mathrm{~V}$.

3) Kestabilan Frekuensi: Parameter kestabilan frekuensi merupakan kemampuan suatu sistem jaringan listrik untuk mempertahankan nilai frekuensi saat beroperasi normal atau setelah terjadi gangguan. Perubahan nilai frekuensi dapat terjadi karena kenaikan besar beban yang diterima oleh genset. Frekuensi elektrik yang dihasilkan oleh generator sinkron terhadap kecepatan putar pada rotor generator. Hubungan antara frekuensi dan kecepatan rotasi pada rotor generator adalah sebagai berikut [11].

$$
f_{e}=\frac{n_{m} P}{120}
$$

dengan

$$
\begin{aligned}
f_{e} & =\text { frekuensi elektrik }[\mathrm{Hz}] \\
n_{m} & =\text { kecepatan rotasi rotor }[\mathrm{rpm}] \\
P & =\text { jumlah kutub. }
\end{aligned}
$$

Mengacu pada Peraturan Menteri Energi dan Sumber Daya Mineral, nilai nominal frekuensi yang berlaku di Indonesia adalah $50 \mathrm{~Hz}$ dan memiliki nilai toleransi sebesar $\pm 1 \%$, yaitu tidak boleh kurang dari 49,5 Hz dan lebih dari 50,5 Hz.

4) Tingkat Kebisingan: Tingkat kebisingan merupakan salah satu aspek penting dalam pemilihan genset. Alat untuk mengukur tingkat kebisingan biasa disebut dengan soundmeter. Tingkat kebisingan memiliki satuan desibel (dB).

$$
d B=10 \log \frac{\text { Pin }}{\text { Pout }}
$$

5) Temperatur Gas Buang: Temperatur gas buang merupakan temperatur gas yang dihasilkan oleh genset yang dibuang melalui saluran pembuangan/knalpot. Gas buang itu sendiri merupakan sisa hasil dari proses pembakaran bahan bakar pada mesin bakar.

\section{SPESIFIKASI DAN PENGUJIAN GENSET}

Studi ini bertujuan untuk menganalisis pengaruh tekanan masukan gas alam pada kinerja teknis genset termodifikasi yang mencakup dua profil kualitas daya berupa kestabilan

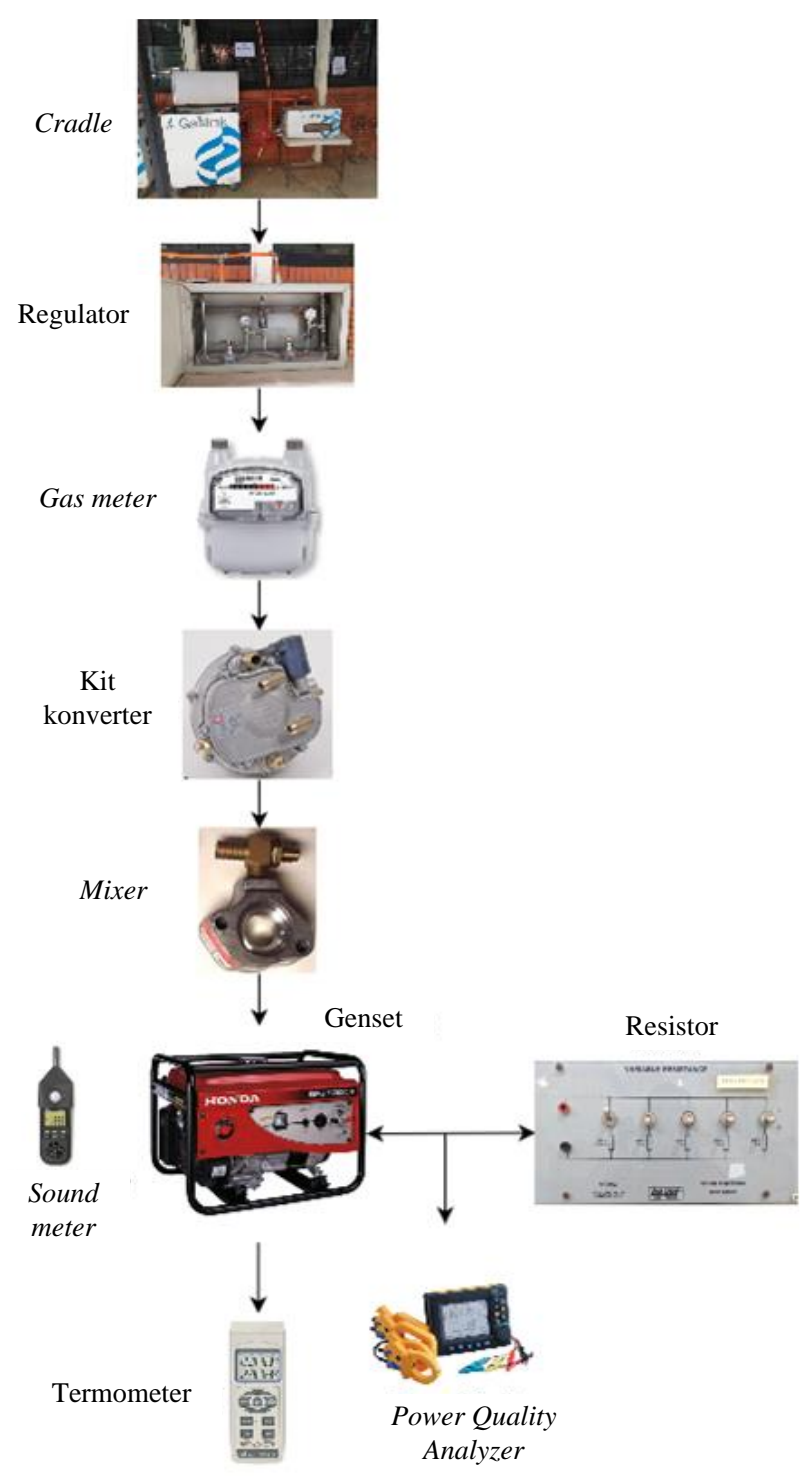

Gbr. 4 Rangkaian pengujian.

tegangan dan frekuensi, SFC, suhu gas buang, dan tingkat kebisingan.

\section{A. Rangkaian Pengujian}

Pada pengujian ini digunakan alat untuk mengukur tingkat kebisingan dan suhu gas buang yang dihasilkan oleh genset, yaitu sound meter dan termometer. Selain itu, digunakan juga gas meter untuk mengukur banyaknya gas yang dikonsumsi genset. Sound meter diletakkan kurang lebih tujuh meter dari posisi genset, sedangkan termometer diletakkan di knalpot gas buang genset. Alat ukur Power Quality Analyzer (PQA) diletakkan di antara beban dan stopkontak keluaran genset. PQA ini berfungsi untuk mengukur profil tegangan, arus, frekuensi, dan energi yang dihasilkan oleh genset. Diagram rangkaian pengujian pada makalah ini ditunjukkan pada Gbr. 4.

\section{B. Spesifikasi Genset Uji}

Genset yang digunakan dalam makalah ini bermerek Honda dengan tipe EP2500CX. Genset ini memiliki kapasitas daya AC 


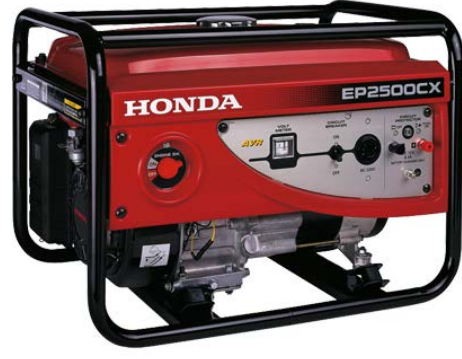

Gbr. 5 Genset Honda EPX2500CX.

TABEL I

SPESIFIKASI GENSET

\begin{tabular}{|l|l|}
\hline \multicolumn{1}{|c|}{ Parameter Spesifikasi Genset } & \multicolumn{1}{c|}{ Nilai } \\
\hline Frekuensi & $50 \mathrm{~Hz}$ \\
\hline Tegangan keluaran AC & $220 \mathrm{~V}$ \\
\hline Daya keluaran AC rata-rata & $2,0 \mathrm{kVA}$ \\
\hline Daya keluaran AC maksimum & $2,2 \mathrm{kVA}$ \\
\hline Keluaran DC & $12 \mathrm{~V} / 8,3 \mathrm{~A}$ \\
\hline Sistem pengaturan tegangan & $\mathrm{AVR}$ \\
\hline Kecepatan mesin & $3.000-3.600 \mathrm{rpm}$ \\
\hline Tingkat kebisingan & $65 \mathrm{~dB}$ \\
\hline
\end{tabular}

TABEL II

TEGANGAN RATA-RATA DI TIAP PEMBEBANAN

\begin{tabular}{|c|c|c|}
\hline \multirow{2}{*}{ Pembebanan } & \multicolumn{2}{|c|}{ Tegangan (V) } \\
\cline { 2 - 3 } & Tekanan 0,5 bar & Tekanan 0,03 bar \\
\hline $25 \%$ & 232,10 & 230,23 \\
\hline $50 \%$ & 230,27 & 228,89 \\
\hline $75 \%$ & 223,80 & 222,04 \\
\hline $90 \%$ & 217,31 & 217,60 \\
\hline
\end{tabular}

rata-rata sebesar 2 kVA. Gambar dan spesifikasi lengkap generator set ini disajikan pada Gbr. 5 dan Tabel I [12].

\section{Skenario Pengujian}

Skenario pengujian yang dilakukan adalah dengan memvariasikan beban yang berupa resistor sebesar 25\%, 50\%, 75\%, dan 90\%. Masing-masing skenario dilakukan sebanyak lima kali. Dengan kapasitas genset sebesar 2.000 watt, maka untuk skenario pembebanan sebesar 25\% dari kapasitas, nilai pembebanannya adalah $25 \% \times 2.000$ watt $=500$ watt.

\section{HASIL DAN ANALISIS}

\section{A. Hasil Pengujian Kestabilan Tegangan}

Hasil tegangan rata-rata dari tiap pembebanan yang terukur pada percobaan menggunakan tekanan masukan 0,5 bar dan 0,03 bar dapat dilihat pada Tabel II. Tampak bahwa tegangan keluaran genset masih dalam batasan grid code di Indonesia.

Gbr. 6 memperlihatkan grafik tegangan rata-rata untuk dua tekanan berbeda pada setiap level beban. Dapat dilihat bahwa level pembebanan memengaruhi nilai tegangan yang dihasilkan oleh genset. Besar tegangan yang dihasilkan berbanding terbalik dengan besar pembeban genset. Hal ini dikarenakan nilai dari tingkat pembebanan berbanding terbalik terhadap kecepatan putar rotor dan tegangan yang dihasilkan, sehingga semakin besar pembebanan, semakin menurun tegangan yang dihasilkan [13].

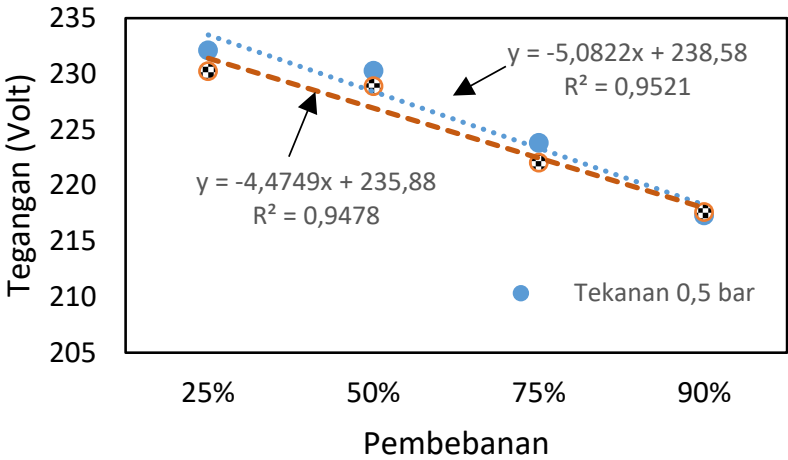

Gbr. 6 Grafik tegangan rata-rata.

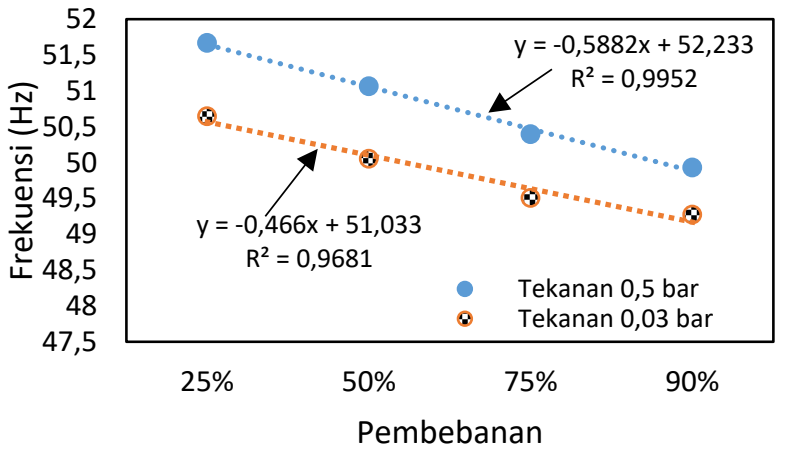

Gbr. 7 Grafik frekuensi rata-rata.

TABEL III

FREKUENSI RATA-RATA DI TIAP PEMBEBANAN

\begin{tabular}{|c|c|c|}
\hline \multirow{2}{*}{ Pembebanan } & \multicolumn{2}{|c|}{ Frekuensi (Hz) } \\
\cline { 2 - 3 } & Tekanan 0,5 bar & Tekanan 0,03 bar \\
\hline $25 \%$ & 51,66 & 50,64 \\
\hline $50 \%$ & 51,06 & 50,05 \\
\hline $75 \%$ & 50,39 & 49,50 \\
\hline $90 \%$ & 49,93 & 49,27 \\
\hline
\end{tabular}

\section{B. Hasil Pengujian Kestabilan Frekuensi}

Hasil frekuensi rata-rata dari tiap pembebanan yang terukur pada percobaan menggunakan tekanan masukan 0,5 bar dan 0,03 bar diperlihatkan pada Tabel III. Sedangkan dari Gbr. 7 dapat terlihat bahwa frekuensi yang dihasilkan, pada saat tekanan masukan 0,5 bar dengan besar pembebanan 75\% dan 90\% dari kapasitas genset, masih dalam batas normal yang mengacu pada Peraturan Menteri Energi dan Sumber Daya Mineral, yaitu 49,5 sampai 50,5 Hz. Sedangkan saat tekanan masukan 0,03 bar, frekuensi yang dihasilkan yang masih dalam batas normal hanya pada saat pembebanan 50\% dan 75\% dari kapasitas genset. Hal ini dikarenakan nilai dari tingkat pembebanan berbanding terbalik terhadap kecepatan putar rotor dan frekuensi yang dihasilkan. Semakin besar pembebanan, semakin menurun frekuensi yang dihasilkan [14].

\section{Hasil Pengujian Specific Fuel Consumption (SFC)}

SFC rata-rata dari tiap pembebanan yang terukur pada percobaan menggunakan tekanan masukan 0,5 bar dan 0,03 bar ditunjukkan pada Tabel IV. Nilai SFC cenderung menurun 


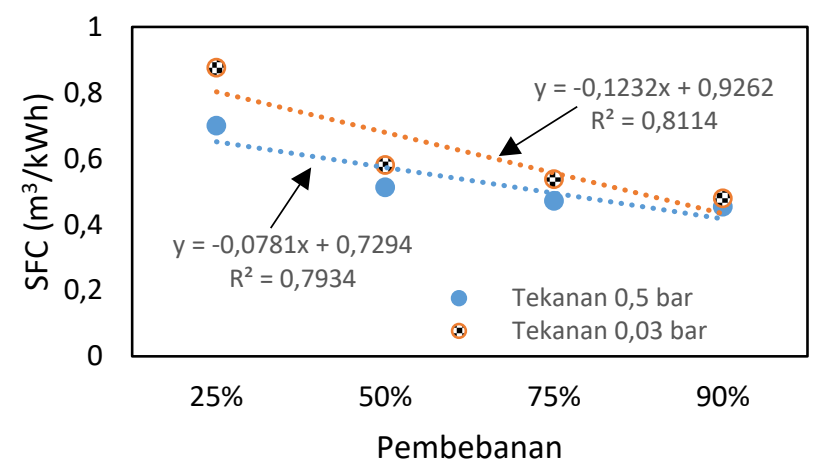

Gbr. 8 Grafik SFC rata-rata.

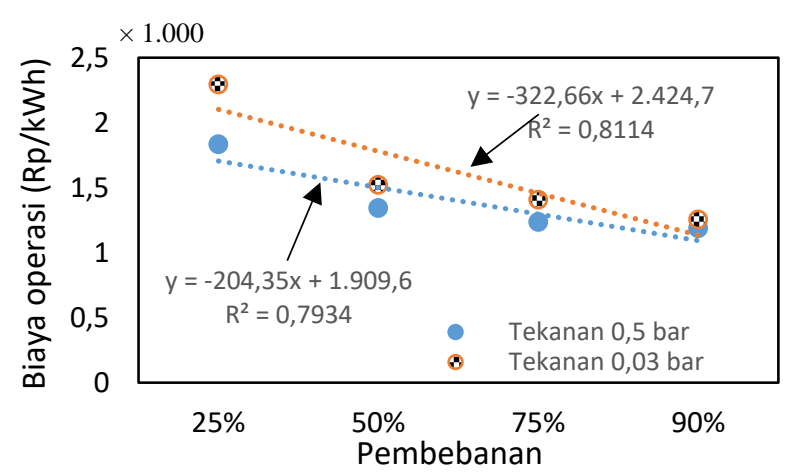

Gbr. 9 Grafik biaya dalam Rp/kWh.

TABEL IV

SFC RATA-RATA DI TIAP PEMBEBANAN

\begin{tabular}{|c|c|c|}
\hline \multirow{2}{*}{ Pembebanan } & \multicolumn{2}{|c|}{ SFC $\left(\mathbf{m}^{\mathbf{3}} \mathbf{/ k W h}\right)$} \\
\cline { 2 - 3 } & Tekanan 0,5 bar & Tekanan 0,03 bar \\
\hline $25 \%$ & 0,69 & 0,87 \\
\hline $50 \%$ & 0,51 & 0,58 \\
\hline $75 \%$ & 0,47 & 0,53 \\
\hline $90 \%$ & 0,45 & 0,48 \\
\hline
\end{tabular}

seiring pertambahan beban, mulai dari $0,69 \mathrm{~m}^{3} / \mathrm{kWh}$ hingga $0,45 \mathrm{~m}^{3} / \mathrm{kWh}$ pada tekanan 0,5 bar dan $0,87 \mathrm{~m}^{3} / \mathrm{kWh}$ hingga $0,48 \mathrm{~m}^{3} / \mathrm{kWh}$ untuk tekanan 0,03 bar. SFC dari genset dengan menggunakan tekanan masukan 0,5 bar lebih rendah 5,7-25\% dibandingkan SFC menggunakan tekanan masukan 0,03 bar pada setiap skenario pembebanan, sebagaimana dapat dilihat pada Gbr. 8.

Pada Gbr. 9 dapat dilihat pula perbandingan biaya dalam $\mathrm{Rp} / \mathrm{kWh}$ dari kedua tekanan masukan dengan asumsi harga gas alam di Jakarta, yaitu Rp2.811,00/的 [15]. Selain itu, besar pembebanan juga memengaruhi nilai SFC yang dihasilkan. Semakin besar nilai pembebaan, semakin kecil SFC yang dihasilkan. Dari Gbr. 8 dapat dilihat bahwa pembebanan $90 \%$ menjadi tingkat pembebanan yang paling efisien untuk generator yang diuji. Hal ini sesuai dengan karakteristik dari spesifikasi genset, yang optimal pada pembebanan 90\% kapasitasnya.

\section{Hasil Pengujian Temperatur Gas Buang}

Pengukuran suhu gas buang yang dihasilkan oleh genset diukur dengan termometer yang diletakkan di knalpot genset.

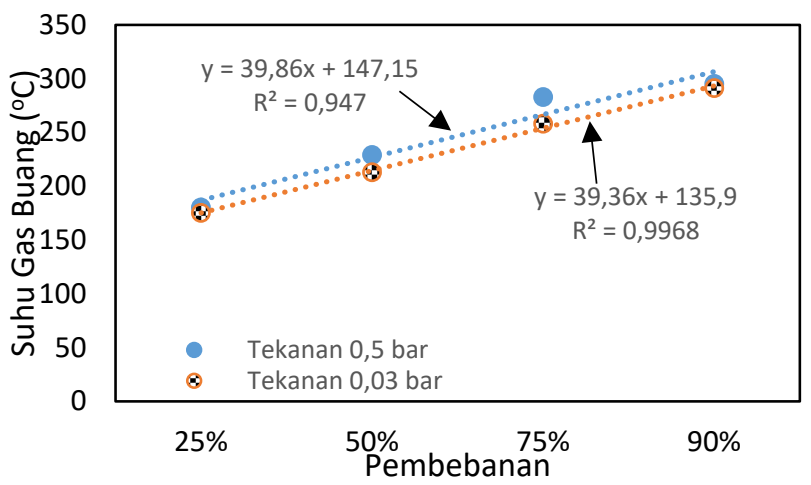

Gbr. 10 Grafik temperatur rata-rata gas buang.

TABEL V

TEMPERATUR GAS BuANG Di TIAP PEMBEBANAN

\begin{tabular}{|c|c|c|}
\hline \multirow{2}{*}{ Pembebanan } & \multicolumn{2}{|c|}{ Temperatur ( $\left.{ }^{\circ} \mathbf{C}\right)$} \\
\cline { 2 - 3 } & Tekanan 0,5 bar & Tekanan 0,03 bar \\
\hline $25 \%$ & 180,2 & 175,1 \\
\hline $50 \%$ & 229,0 & 212,8 \\
\hline $75 \%$ & 282,9 & 258,1 \\
\hline $90 \%$ & 295,1 & 291,2 \\
\hline
\end{tabular}

TABEL VI

TingKat Kebisingan RATA-RATA Di TIAP PEMBEBANAN

\begin{tabular}{|c|c|c|}
\hline \multirow{2}{*}{ Pembebanan } & \multicolumn{2}{|c|}{ Tingkat Kebisingan (m³ $\mathbf{3}$ Wh) } \\
\cline { 2 - 3 } & Tekanan 0,5 bar & Tekanan 0,03 bar \\
\hline $25 \%$ & 66,84 & 67,08 \\
\hline $50 \%$ & 66,92 & 67,50 \\
\hline $75 \%$ & 68,62 & 67,72 \\
\hline $90 \%$ & 68,74 & 68,74 \\
\hline
\end{tabular}

Nilai suhu yang dihasilkan berdasarkan skenario pembebanan dan tekanan masukan diperlihatkan pada Tabel V.

Gbr. 10 menunjukkan bahwa suhu gas buang yang dihasilkan oleh genset ketika menggunakan tekanan 0,5 bar dan 0,03 bar tidak berbeda jauh. Hal ini dikarenakan tekanan masukan ke genset tidak memengaruhi temperatur hasil pembakaran yang terjadi di ruang bakar mesin. Selain itu, semakin besar pembebanan pada genset, semakin besar pula temperatur gas buang yang dihasilkan. Hal ini disebabkan proses pembakaran yang terjadi memerlukan energi yang lebih besar seiring dengan kenaikan beban, sehingga jumlah bahan bakar yang masuk ke dalam ruang bakar untuk memberikan daya mesin bertambah terhadap kenaikan beban listrik.

\section{E. Hasil Pengujian Tingkat Kebisingan}

Pengukuran tingkat kebisingan yang dihasilkan oleh genset diukur dengan sound meter yang diletakkan kurang lebih tujuh meter dari genset. Nilai tingkat kebisingan yang dihasilkan berdasarkan skenario pembebanan dan tekanan masukan dapat dilihat pada Tabel VI.

Lalu, terlihat pada Gbr. 11 bahwa nilai tertinggi dari tingkat kebisingan yang dihasilkan oleh genset berada pada saat skenario pembebanan $90 \%(1,8 \mathrm{~kW})$, dengan rata-rata tingkat kebisingan sebesar 68,74 dB untuk tekanan 0,5 bar dan tekanan 0,03 bar. Tingkat kebisingan yang dihasilkan lebih tinggi 


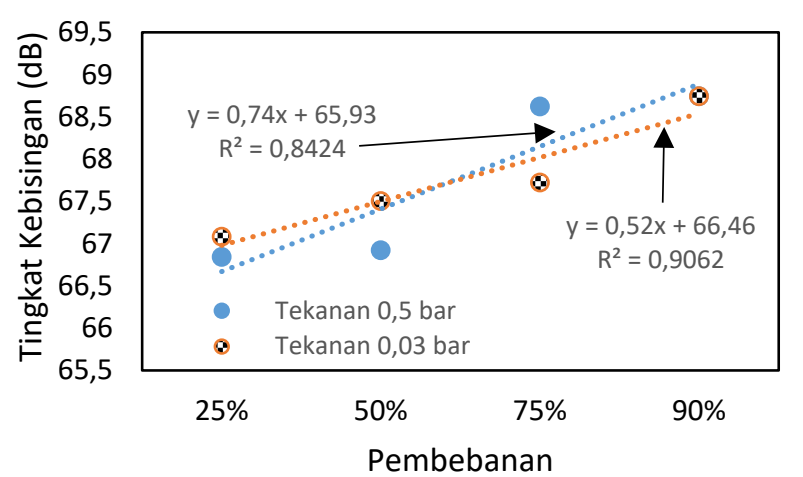

Gbr. 11 Grafik tingkat kebisingan rata-rata.

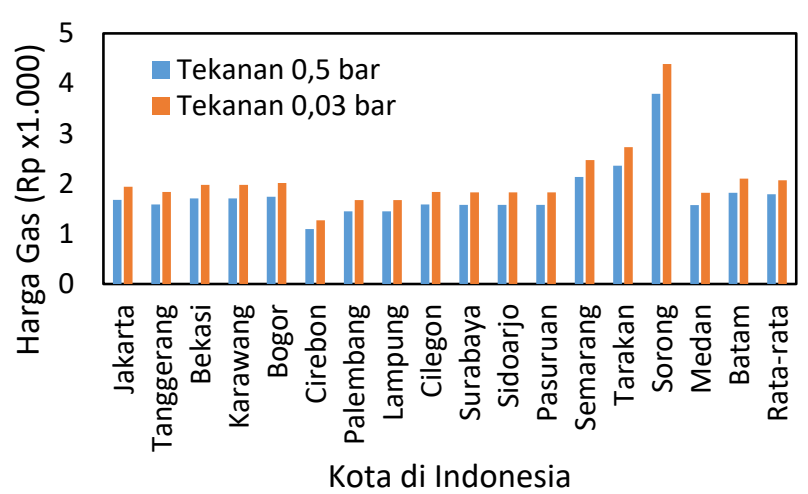

Gbr. 12 Grafik perbandingan harga gas di Indonesia.

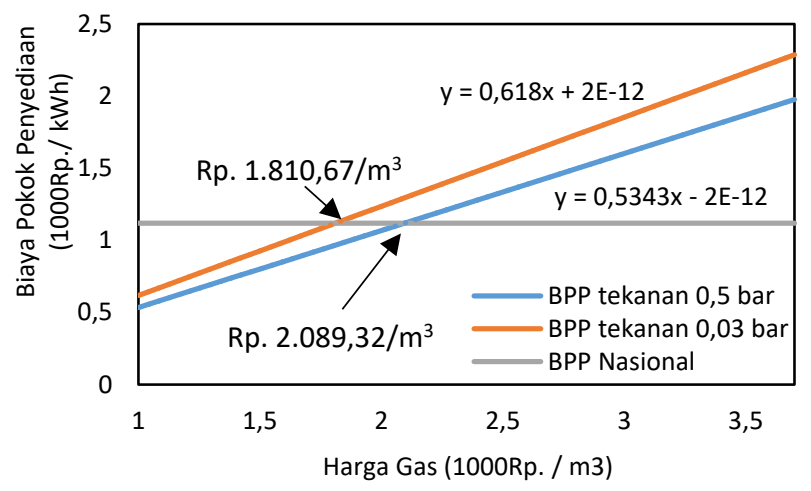

Gbr. 13 Paritas grid genset termodifikasi.

sedikit apabila diibandingkan dengan spesifikasi yang tertera. Hal ini dikarenakan pengukuran dilakukan di ruang terbuka, sehingga ada kontribusi suara sekitar yang tidak teredam terhadap hasil pengukuran yang telah dilakukan.

\section{F. Analisis Tekno Ekonomis}

Detail perbandingan biaya operasi untuk kedua tekanan gas ditentukan oleh harga gas yang tersedia di pasar. Harga gas pada beberapa kota di Indonesia dapat dilihat pada Gbr. 12 [15]. Tampak bahwa di kota-kota besar, baik di pulau Jawa maupun Sumatera, khususnya yang memiliki eksplorasi dan cadangan gas, harga jual gas cukup kompetitif, sehingga dapat bersaing dengan harga listrik dari PLN maupun sebagai cadangan dalam menyuplai listrik, termasuk solusi alternatif bagi daerah T3 di Indonesia yang memiliki akses ke gas alam.
Selanjutnya, paritas grid (grid-parity) yang mengilustrasikan genset termodifikasi ini dapat bersaing dengan BPP nasional ditunjukkan pada Gbr. 13. Berdasarkan grafik tersebut, dapat dilihat trennya bahwa pada tekanan 0,5 bar, agar BPP genset termodifikasi dapat bersaing dengan BPP Nasional, harga gas harus kurang dari atau sama dengan $\mathrm{Rp} 2.089,32 / \mathrm{m}^{3}$. Sedangkan untuk tekanan 0,03 bar, besar harga gas harus kurang dari atau sama dengan Rp1.810,67/m³. Oleh karena itu, selama harga gas masih di bawah kedua titik tersebut, BPP genset termodifikasi ini masih dapat bersaing dengan BPP listrik nasional.

\section{KESIMPULAN}

Hasil dari studi mengenai genset termodifikasi ini adalah tegangan yang dihasilkan genset untuk tekanan 0,5 bar dan 0,03 bar masih dalam batas normal yang ditentukan. Selain itu, frekuensi yang dihasilkan ketika tekanan 0,5 bar berada pada batas normal ketika pembebanan $75 \%$ dan $90 \%$, sedangkan pada tekanan gas 0,03 bar, kondisi frekuensi normal hanya saat pembebanan $50 \%$ dan $75 \%$. Nilai SFC yang dihasilkan ketika tekanan masukan 0,5 bar lebih kecil 5,7-25\% dibandingkan tekanan masukan 0,03 bar. Suhu gas buang yang dihasilkan ketika tekanan masukan 0,5 bar dan 0,03 bar relatif sama dan tingkat kebisingan yang dihasilkan genset termodifikasi pada tekanan masukan 0,5 bar dan 0,03 bar terukur lebih tinggi sebesar 2,83-5,75\% dibandingkan spesifikasi yang tertera.

Berdasarkan hasil studi ini, maka genset termodifikasi dengan masukan gas alam ini dapat dijadikan sumber energi listrik alternatif untuk daerah yang belum terjangkau listrik atau sebagai back-up di daerah perkotaan pada saat kondisi listrik dari jaringan terputus. Meskipun demikian, ada beberapa hal lainnya yang dapat diinvestigasi lebih dalam lagi terkait hasil studi ini untuk penelitian yang mendatang. Hal tersebut mencakup studi kualitas daya keluaran genset jika dikombinasikan dengan pembangkit energi baru terbarukan seperti sistem photovoltaic (PV), baik dikaji dari sisi teknis maupun ekonomis. Selain itu, dapat diinvestigasi juga profil kualitas daya, khususnya terkait gangguan pada jaringan listrik dengan pembebanan yang bervariasi, terutama beban real peralatan rumah tangga, sehingga dampak negatif yang ditimbulkan oleh peralatan rumah tangga yang berjenis beban nonlinear tersebut dapat dikaji lebih dalam lagi terhadap keluaran genset ini.

\section{UCAPAN TERIMA KASIH}

Penelitian ini didanai oleh hibah penelitian HIBAH PUTI No. NKB-1190/UN2.RST/HKP.05.00/2020 dari Direktorat Riset dan Pengabdian Masyarakat Universitas Indonesia (DRPM-UI).

\section{REFERENSI}

[1] (2019) "Rencana Usaha Penyediaan Tenaga Listrik PT. PLN (Persero) 2019-2028,” [Online], http://gatrik.esdm.go.id/assets/uploads/ download_index/files/5b16d-kepmen-esdm-no.-39-k-20-mem-2019tentang-pengesahan-ruptl-pt-pln-2019-2028.pdf, tanggal akses: 11-Mar2020.

[2] Sekretariat Perusahaan PT PLN (Persero), Statistik PLN 2018, Jakarta, Indonesia: Sekretariat Perusahaan PT PLN (Persero), 2019.

[3] H. Ali, A. Rahardjo, A. Setiawan, F.H. Jufri, dan F. Husnayain, "Voltage Profile Improvement Analysis During the Loss of Transmission Lines on 
150 kV Subsystem Using Static Synchronous Compensator," IOP Conf. Ser. Mater. Sci. Eng., Vol. 673, hal. 1-7, 2019.

[4] British Petroleum, "BP Statistical Review of World Energy," British Petroleum Report, 2018.

[5] T.W. Hesterberg, C.A. Lapin, dan W. B. Bunn, "A Comparison of Emissions from Vehicles Fueled with Diesel or Compressed Natural Gas,” Environ. Sci. Technol., Vol. 42, No. 17, hal. 6437-6445, Sep. 2008.

[6] G. Alvianingsih dan I. Garniwa, "A Design of Palm Oil and Diesel Oil Fuel Mixture Heater System for Small Scale Diesel Power Plant," 2017 Int. Conf. on High Voltage Engineering and Power Systems (ICHVEPS), 2017, hal. 156-164.

[7] (2018) "Laporan Tahunan Capaian Pembangunan 2018," [Online], https://migas.esdm.go.id/uploads/uploads/files/laporan-tahunan/LaptahMigas-2018---FINAL.pdf, tanggal akses: 12-Mar-2020.

[8] R.K. Mobley, Fluid Power Dynamics, $1^{\text {st }}$ ed., Oxford, UK: ButterworthHeinemann, 2000.

[9] N. Sinaga, "Perancangan Awal Converter Kit LPG Sederhana untuk Konversi,” J. Tek. Energi, Vol. 13, No. 1, hal. 1-9, Jan. 2017.
[10] R.C. Dugan, M.F. McGranaghan, S. Santoso, dan H.W. Beaty, Electrical Power Systems Quality, $3^{\text {rd }}$ ed., New York, USA: McGraw-Hill Professional, 2012.

[11] S.J. Chapman, Electric Machinery Fundamentals, $5^{\text {th }}$ ed., New York: USA: McGraw-Hill, 2012.

[12] “Honda ER2500CX Owner's Manual," Honda Motor, 2014.

[13] A. Triatmanto, "Pengaruh Kecepatan Putar dan Kapasitor Pararel pada Belitan Bantu Terhadap Keluaran Generator Induksi 1 Fase 6 Kutub," Skripsi, Universitas Muhammadiyah Surakarta, Surakarta, Indonesia, 2016.

[14] H. Dewi, F.H. Jufri, dan C. Hudaya, "Techno-Economic Analysis of Slip Ring Motor Replaced by Standard Squirrel Cage Induction Motor with VSD," J. Phys. Conf. Ser., Vol. 1402, No. 3, hal. 1-6, 2019.

[15] Direktorat Jenderal Minyak dan Gas Bumi, Neraca Gas Bumi Indonesia 2018-2027, Jakarta, Indonesia: Direktorat Jenderal Minyak dan Gas Bumi, Kementerian Energi dan Sumber Daya Mineral, 2018. 